\title{
Translation as translating as culture
}

\author{
Peeter Torop \\ Deptartment of Semiotics, University of Tartu, \\ Tiigi 78, Tartu 50410, Estonia \\ e-mail: torop@ut.ee
}

\begin{abstract}
The most common difficulty in translation studies has traditionally been the dilemma between the historical and synchronic approaches in the analysis and description of the culture of translation. On the one hand the culture of translation might be presented as the sum of various kinds of translated texts (repertoire of culture), on the other hand it might be described as the hierarchy of the various types of translations themselves. The first approach assumes plenty of languages for such description, in the latter one suggests only one language for the same representation. A cultural critic faces the same problems. In these perspectives the translation reveals important mechanisms of the performance of culture. First of all it is the semiotic interpretation of the theory of translation, introduced by the number of scientists beginning with R. Jakobson and including U. Eco who put together interlinguistic, intra-linguistic, and inter-semiotic translations, so crucial for the further understanding of culture. As a result, the general notion of culture might be described as the process of total translation. And secondly, the other valuable contribution to the theory of translation has been made by both $\mathrm{M}$. Bakhtin and J. Lotman in terms of the synthesis of two traditions in semiotics of culture resulted in juxtaposing such notions as dialogism and autonomy creolization, polyphony, counterword, and translation.
\end{abstract}

Translating as an activity and translation as the result of this activity are inseparable from the concept of culture. The translational capacity of culture is an important criterion of culture's specificity. Culture operates largely through translational activity, since only by the inclusion of new texts into culture can the culture undergo innovation as well as perceive its specificity. After the expansion of the paradigm of postcolonial and the related field of gender studies into translation studies, the borderline between culture studies and translation studies has become fuzzier, yet at the same time, there has emerged a visible 
complementarity. On the one hand, by the turn of the century, the understanding of the cultural value of a translation text has grown deeper, especially in respect to the importance of translations for the identity of the receiving culture. L. Venuti has called the identityforming power of translations this ability of translations to participate, according to the necessity, both in ensuring culture's coherence or homogeneity as well as in activating cultural resistance or culture's innovation processes (Venuti 1998: 68).

On the other hand, culture theory, particularly in the area of cultural studies, has again begun to value the concept of identity through culture. Due to the activity of the topic of globalisation and the opposition of the global and the local, the understanding has been reached once again that no society wishing to enact its specificity can escape the consideration of cultural identity. The comprehension of the utmost necessity of cultural identity for the perception of political, social, economic and technological development has even been called the cultural turn: "The fact that cultural identity is the decisive factor in constructing the specificity of a certain society could be called the "cultural turn". It means a.o. that contemporary political and social developments, but also economic and technological developments, whether they have a global or rather a local nature, can only be understood via the concept of cultural identity..." (Segers 2000: 384-385).

Although there are several disciplines engaged in the study of culture, we can speak of neither a methodologically unified research into culture, nor of a general theory of culture. As an object of study culture allows for too many different definitions for this to be possible. In translation studies the possibilities of defining the object of study are considerably more limited, but the problem of unified methodology is bound to arise even here. Comparing the two fields, especially projecting the development problems of translation studies upon cultural theory, comes most naturally. Translation studies attempt to solve, although on a smaller scale, the same problems that have been facing cultural theory for some time already. This happens both on the object level and on the metalevel.

On the metalevel, attempts have been made in translation studies to regulate the specific metalanguage, as difficulties in understanding have appeared between different scholarly traditions of studying translation. Therefore calls have been made that works in translation studies be written in a generally comprehensible language, in the language of average scholarship, as it were. On the other hand, there have been attempts to create a situation of methodological translatability in 
which different translation theories could be compared or possibilities of interdisciplinary synthesis could be searched for.

On the object level, the first problem is that of the secondary nature of translation. The difficulties arising in writing a translation history clearly show that proceeding from periods, translated authors, translated works or translators does not guarantee a description concerning the content. If the works of an author have been translated during a period of two hundred years and dozens of translations have been made of them, it seems possible to arrange them all along a scale between good and bad translation. However, the hundred years remaining between two translations do not allow us to compare them in such a manner. A typology is required, based on the distinction of different translation types according to certain characteristics. These characteristics can be external, but they can also be derived from a general model of the translation process.

Thus, the translation culture of a particular period can be viewed as a certain number of translated texts in one case, or as a hierarchy of translation types in another case. In the former case we can speak of the choice, cultural politics and cultural repertoire, the functioning of translated texts in a new culture. In the latter case we can discuss the translations themselves, translation methods and the translators' works. In the former case we can use very different languages of description, in the latter case we need comparative terms to denote types of translation, and thus a relatively unified metalanguage is required.

How is all this connected to the working mechanism of culture? The connectedness can be observed from two aspects. The first aspect derives from the fact that, thanks to Roman Jakobson's works, a semiotic turn took place on the borderline between translation studies and cultural semiotics. The scope of translation as a term widened and the methodology of translation studies started to change due to the differentiation between three kinds of translation activities. R. Jakobson distinguished intra-lingual translation or interpretation of verbal signs by verbal signs of the same language (sign system). The translation within a system of signs is related to paraphrasing, changing of genres and discourses. As a second type of translation R. Jakobson mentioned inter-lingual translation that means interpretation of verbal signs with the verbal signs of another language (sign system) and is thus translation in the ordinary sense. As a third type of translation R. Jakobson suggested intersemiotic translation or transmutation that means interpretation of the signs of a sign system with the signs of 
another sign system. In this way, also translating literature into film or theatre productions, the translatability of word into picture and vice versa became visible to translation studies (Jakobson 1971).

To the three main types of translation, R. Jakobson's article adds the understanding of translation process as two processes taking place simultaneously, recoding and transposing. But the distinction between the changing and the retaining processes forms only the individual or individual psychological aspect of translation, although it is certainly impossible to create a model of translational activity without this aspect. However, also the general cultural or cultural psychological aspect is worth distinguishing. R. Jakobson stresses the semiotic value of all five senses in the human society ("All five external senses carry semiotic functions in human society” - Jakobson 1971a: 701), bringing thereby communication and autocommunication closer together. With respect to the study of communication processes, R. Jakobson stresses the importance of distinguishing between homogeneous messages, i.e. those based on a single sign system, and syncretic messages, i.e. those based on the combination of several sign systems. "The study of communication must distinguish between homogeneous messages which use a single semiotic system and syncretic messages based on a combination or merger of different sign patterns" (Jakobson 1971a: 705). Thus the differentiation of three translation types proceeds from R. Jakobson's general understanding of the communication process and the types of messages.

As a result of the semiotic turn several new conceptions arose within or on the borderline of translation studies. James Holmes introduced the concept of metaliterature in which all texts generated on the basis of one text were united into a single system (Holmes 1988). Anton Popovič developed his own theory of metatexts that also saw all secondary texts as a unified metacommunicative system. However, he observed the same processes both on the level of whole texts, as well as on the level of parts of texts. It is thanks to him that for instance quoting became analysable as a translation activity. Linking communication and metacommunication allowed him to create his own treatment of culture (Popovič 1975). Proceeding in the same direction the author has been expanding John Catford's notion of total translation and observed within this framework different translation types that can all be described on the basis of the model of a universal translation process. The types are textual translation or ordinary translation; metatextual translation or description via criticism, advertising and other texts of this kind; in-textual and intertextual 
translation or transmitting or introducing a foreign word into a text, and extratextual translation or translating out of a text, using other semiotic material, for instance, in adapting literature to film (Torop 1995, complemented in Torop 2000).

The transformation of Jakobson's classification is also important. This was first done by Gideon Toury who restructured Jakobson's schema for the Encylopedic Dictionary of Semiotics. First and foremost, Toury differentiates between two types of translation - intrasemiotic translating and intersemiotic translating. Intersemiotic translating involves translating from language to non-language. Intrasemiotic translation can be divided into two subtypes - intrasystemic translating and intersystemic translating. Intrasystemic translation corresponds to Jakobson's intralinguistic translation and intersystemic translation in its turn answers to interlinguistic translation (Toury 1986).

The hitherto latest contribution to the development of Jakobson's classification has been made by Umberto Eco in his book Experiences in Translation (2001). Eco starts from Ch. S. Peirce's influence on Jakobson. On the one hand, Eco emphasises Peirce's statement "that meaning, in its primary sense, is a 'translation of a sign into another system of signs" (Eco 2001: 69). On the other hand, he shows that the closeness of the concepts of translation and interpretation in Jakobson's case derives from the impressionistic quality of Peirce's metalanguage. Ch. S. Peirce "uses translation in a figurative sense: not like a metaphor, but pars pro toto (in the sense that he assumes 'translation' as a synecdoche for 'interpretation')" (Eco 2001: 69). Eco's own summary follows this logic — "translation is a species of the genus interpretation, governed by certain principles proper to translation" (Eco 2001: 80).

Eco's classification is, like that of Jakobson's, tripartite. Firstly, there is interpretation by transcription. This involves simple substitution of codes as, for example, in case of the Morse alphabet. Secondly, there is intrasystemic interpretation. This, in its turn, can be divided into three subcategories: intrasystemic interpretation within the same natural language (as, for instance, synonymy, definition, paraphrase, inference, comment etc.); intrasystemic interpretation within other semiotic systems (for instance, changing a piece of music from major to minor); and performance (for example, the performance of a musical score or the staging of a ballet). Thirdly, Eco introduces intersystemic interpretation that includes two types, one with marked variation in the substance, and the other with mutation of continuum. 
Intersystemic interpretation with marked variation in the substance includes three subtypes: interlinguistic interpretation or translation between natural languages; rewriting (e.g., reworked versions of the same piece by the same composer, parody); translation between other semiotic systems or intersystemic interpretation with very marked differences in substance among non-linguistic systems (for instance, transforming a colourful oil painting into a black and white reproduction). Mutation of continuum includes parasynonymy and adaptation or transmutation. Parasynonymy can be illustrated by amplifying the phrase "that one over there" by pointing at the object with a finger. Adapting literature to film or to theatre belongs to adaptation or transmutation (Eco 2001: 100-128).

Several other, more local works, could be added to Eco's book that emphatically announce intersemiotic translation as radical translation to be the best means of lending meaning to any kind of translation activity. Intersemiotic translation makes implicit aspects of interlinguistic translation explicit. Methodologically the tradition that has its roots in Jakobson and in part also in Peirce has been characterized by bringing the concepts of meaning, interpretation and translation close to one another and viewing culture as a mechanism of translation.

Another aspect that can be linked to translation as a working mechanism of culture is that of semiotics of culture, but in a fairly specific sense. It is the points of contact between the traditions of $\mathrm{M}$. Bakhtin and J. Lotman. Lotman and Bakhtin have been juxtaposed and contrasted to each other, and this has happened on different levels. In case of Bakhtin it is important that although he has not directly been concerned with translation problems as such, scholars still find reasons to write about him in connection with issues of translation (Emerson 1993, Robel 1995, De Michiel 1999). Leon Robel emphasises that Bakhtin attributes to the language of literature (and, at the same time, also the text) the capacity to operate as a metalanguage in translating from one sign system into another. For him, the text is a set of translations that differ in their meaning (Robel 1995). Margerita De Michiel, however, makes the translation text her basis and sees it as a place of multi-level dialogism in Bakhtin's system: "A translation text is a place where a dialogue takes place: between texts and practices, between empirical practice and theoretical practice, between science and ideology. It is a dia-logic place, for at least two different logics meet in it: those of two different languages" (De Michiel 1999: 695). 
L. Robel and M. De Michiel implicitly express a most important dualism in Bakhtin's logic.

The treatise published under the name of Valentin Voloshinov Marxism and the Philosophy of Language suggests that

any element of an utterance that forwards a thought and is being foregrounded, or even a full utterance is translated by us into corresponding context that is different and active. Any understanding is dialogic. Understanding is contrasted to utterance as a speaker's words are contrasted to those of another speaker in a dialogue. Understanding is looking for a counterword to the word of a speaker. Only understanding of a foreign word seeks for "a similar" word in the native language.

[каждый выделимый смысловой элемент высказывания и все высказывание в целом - переводятся нами в иной, активный, отвечающий контекст. Всякое понимание диалогично. Понимание противостоит высказыванию как реплика противостоит реплике в диалоге. Понимание подыскивает слову говорящего противослово. Только понимание чужеземного слова подыскивает "то же самое" слово на своем языке.] (Bakhtin 2000a: 436).

Several scholarly works have been dedicated to the comparison of M. Bakhtin's and J. Lotman's dialogisms (Shukman, Lachmann, Danow, Bonafin), but the simultaneity of the dual understanding has not been stressed much. In essence, this is a situation in which understanding is a process that on the one hand creates differences (word and the counterword), and, on the other hand, similarities (word and its translation). And if the dialogism of understanding is borne in mind, we can in principle talk about two types of dialogue.

One of Bakhtin's central concepts to denote the unique status of Dostoyevski's novels in world literature is polyphony or polylogue. The characters of an ordinary novel are, according to Bakhtin's logic, objects of representation for the authors. Dostoyevski, however, frees the characters from the author's sway over them and makes them into independent subjects. This is accompanied by a multiplicity of different subjects that allows us to speak about the polyphonic novel as coexistence of several equal subjects and, by extension, also ideas, of a choir of different voices. Against the background of polyphony, Bakhtin has listed three interconnected phenomena as first discovered by Dostoyevski: firstly; a new way of representing people, according to which a human being is "an alien consciousness of full and equal rights and of full meaning that has not been set in the finishing frame of reality" (“полноправное и полнозначное чужое сознание, не вставленное в завериающую оправу действительности”) and the 
interpretation of which, accordingly, is a dialogic process. Secondly, the representation of the independent development of an idea that cannot be separated from personality not within the framework of a philosophical or some other system, but as a human event. Thirdly, dialogism as a particular form of mutual influences of consciousnesses with equal rights and meanings (Bakhtin 1996: 340-341). According to this, polyphony as a whole is an artistic "will to unite several single wills, a will to reach an event”(“воля к сочетанию многих воль, воля к событию”) (Bakhtin 2000b: 29).

From the point of view of cultural analysis it must be admitted that any culture is analysable in a polylogic manner or as a polylogue due to its heterogeneity. But already in Bakhtin's logic an important principle is revealed - the polylogue of a culture cannot be analysed as a sum total of monologues, for culture as a whole operates through dialogic relationships between monologues and a polylogue is thus an intertwined phenomenon. What is necessary to understand this intertwining is studying and understanding the space in which it takes place, the cultural space. And, within this space, it is necessary to understand the situation that creates dialogue or is accompanied by dialogue - to understand the event or the text.

Culture has its own sign systems or languages on the basis of which the members of the culture communicate. Thus, one possibility to understand a culture is to learn the languages of the culture, the sign systems operating within the culture. The languages of culture are, however, apt to change and their signs are ambiguous. Thus another possibility remains to approach the culture via events and texts that bind different sign systems, yet have a general meaning or theme that can be described.

Even on the level of an ordinary natural language Bakhtin already a long time ago brought forth the semiotic polarity of meaningfulness. He signified the poles with the notions of theme and meaning. Bakhtin called the theme the highest real boundary of linguistic meaningfulness, for only a theme is defined. Accordingly, he called meaning the lowest boundary of linguistic meaningfulness for meaning does not mean, but is a potential, an ability to have meaning within the framework of a theme (Bakhtin 2000a: 435-436).

Bakhtin's scholarly reception is related to these two poles as well. A polylogic approach to culture still gives priority to the coexistence of different (linguistic, cultural, semiotic etc.) autonomies and observes the differences of differences. A dialogic polylogism gives priority to links and mixing of autonomies; and, beside the differing of 
differences, it also observes the differences between samenesses or the sameness of differences. This has been called "heterology" by Tz. Todorov who has declared in a fit of polemics, "heterology that makes the differences between voices audible, is necessary; polylogy is dull and empty" (Todorov 1982). One of the first people to introduce Bakhtin to the world at large, Julia Kristeva, has stressed the ambivalence of Bakhtin's system; considering the same poles, she juxtaposed the polyphonic novel with Menippean satire as a heterologic phenomenon.

To explain heterology as a concept we should return to the time when Bakhtin was most active. Some dozen years before Bakhtin introduced the concept of polyphony, a dictionary of musical terms $A$ Guide to Concerts by B. Asafyev (1919) was published in Russia. This booklet, that has had considerable influence on the metalinguistic thought of its period, defines several concepts of the theory of music as general and theoretical ones. When it is read through the prism of Bakhtin's works that were to follow, also the notion of heterophony opens up in this way. Heterophony "is not yet polyphony in its developed (articulated) form, in which each voice has an independent meaning, but one of the stages in the transition to polyphony (in which all voices form an intricate horisontal complex that is moving and continuously changing)" (“еще не многоголосие (полифония) в развитом (дифференцированном, расчлененном) виде, когда каждый голос получает самостоятельное значение, а одна из переходных к многоголосию стадий [...] (когда все голоса образуют сложный подвижный непрерывный изменчивый горизонтальный комплекс)" (Asafjev 1978: 31-32). Thus, if we proceed from this logic, polyphony creates a vertical dimension, a dimension of diverse voices differing from one another.

An ethnological description of culture or one deriving from cultural anthropology is first and foremost polylogic, for it fixes the cultural languages that differentiate themselves intelligibly (i.e. can be described) and these are described in an autonomous way. This is what Clifford Geertz opposed. Semiotics of culture, however, started to fill an important gap - to describe the complexes, the intertwining of the languages of culture. J. Lotman drew distinctions between two different processes in his description of culture. One is the specialisation of languages of culture (e.g. as the autonomy in culture of photography or film as the result of new technical developments). Another is the integration of languages of culture, that can be marked firstly by the appearance of metadescriptions and autometadescrip- 
tions (or culture's attempt to make itself conscious through criticism, theory, the media etc.); and, secondly, by creolisation (merging of cultural languages), starting from experimental cases (the transitions between literature- theatre-film) to the mergings on the levels of the high and the low, of style and stylelessness, of genre characteristics (Lotman 2000: 572-575).

Against the background of Lotman's synthesis, synthesis on a new level is important. The analysis based on the description of pure phenomena or polyphonic analysis, and the analysis based on impure (mixed) phenomena or heterophonic analysis complete each other. This happens both on the level of the culture itself, as well as on the level of describing the culture. It is no accident that U. Eco in his preface to J. Lotman's work titled Universe of the Mind that was published in the United States in 1990 mentioned that the most interesting moment occurred when Lotman took up analysis of the creolization of cultural codes.

Thus it is inevitable to have the two possible types of analysis continuously in mind. Restricting oneself to impure systems only will reach, in its extreme version, postmodernist simulacra, such as J. Baudrillard's concepts of transaesthetics (arbitrary reception of a work of art), transpolitics (differences between parties and ideologies that cannot be told apart), transsexuality (the loss of the sexual dominant in culture, approaching the state of a robot or a dummy etc), transeconomics (loss of accounting in economic processes) (Baudrillard 1990).

When Lotman wrote in Universe of the Mind that an "elementary act of thinking is translation" (Lotman 1990: 143), he also took the following logical step, stating that "elementary mechanism of translating is dialogue" (Lotman 1990: 143).

What I would like to contend is that the situation that has arisen in translation studies is in many of its aspects also a situation concerned with the theory of culture. This has been grasped in the semiotics of culture by introducing intersemiosis beside the concept of semiosis. This is not a tautology. Also, apprehensive attitudes are apparent in case of several scholars. M. Riffaterre who dedicated a whole article to the defence of intertextuality against hypertextuality can serve as an eloquent example. In the former notion he sees a programme and a system that can be made explicit, in the latter he notices but arbitrary links. His fear that a lack of system will be studied as a system is actually fear of complementariness (Riffaterre 1994).

The changing nature of boundaries within a culture requires twofold competence from the scholar engaged in cultural analysis - the 
ability to analyse autonomous phenomena and the ability to analyse creolisation, and mixtures, for it is the proportion between autonomy and creolisation that best explains the present state of a culture and its dynamics. In the discipline of semiotics of culture it comes naturally to say that culture is translation, and also that translation is culture. However, in the present context it should be added that translation activity is also an activity that explains the mechanisms of culture and that translation itself is a concept that is extremely loaded methodologically. Still, the fact that translation as a concept is loaded does not mean it is metaphorised. Translation and translating are concepts concurrent with an active culture and allow us in the situation of the scarcity of culture theoretic means to approach the essence of cultural mechanisms in a way that the analysis of both translation and translating as well as culture are enriched.

\section{References}

Asafjev 1978 = Асафьев, Борис. Путеводитель по концертам (Словарь наиболее необходимьхх терминов и понятий). Изд. 2-е. Москва: Советский композитор.

Bakhtin 1996 = Бахтин, Михаил М. Собрание сочинений. Т. 5. Москва: Русские словари.

- 2000а. Бахтин, Михаил М. Фрейдизм. Формальный метод в литературоведении. Марксизм и философия языка. Статьи. Москва: Лабиринт.

- 2000b. Бахтин, Михаил М. Собрание сочинений. Т. 2. Москва: Русские словари.

Baudrillard, Jean 1990. La transparence du mal: Essai sur les phénomènes extrêmes. Paris: Galilee.

Bonafin, Massimo 1997. Typology of culture and carnival: Note on the models of Bachtin and Lotman. Russian Literature 41(3): 255-268.

Danow, David K. 1991. The Thought of Mikhail Bakhtin: From Word to Culture. Houndmills: Macmillan.

De Michiel, Margherita 1999. Mikhail M. Bakhtin: Prolegomena to a theory of translation. European Journal for Semiotic Studies 11(4): 687-698.

Eco, Umberto 1990. Introduction. In: Lotman 1990: 7-13.

- 2001. Experiences in Translation. Toronto: University of Toronto Press.

Emerson, Caryl 1993. Translating Bakhtin: Does his theory of discourse contain a theory of translation? Revue de l'Université d'Ottawa 53(11): 11-22.

Geertz, Clifford 1993. The Interpretation of Cultures. Selected Essays. London: Fontana Press.

Holmes, James S. 1988. Translated! Papers on Literary Translation and Translation Studies. Amsterdam: Rodopi. 
Jakobson, Roman 1971. On linguistic aspects of translation. In: Jakobson, R., Selected Writings. 2. Word and Language. The Hague: Mouton, 260-266.

- 1971a. Language in relation to other communication systems. In: Jakobson, R., Selected Writings. 2. Word and Language. The Hague: Mouton, 697-708.

Lachmann 1995 = Лахманн, Ренате. Ценностные аспекты семиотики культуры/семиотики текста Юрия Лотмана. In: Пермяков, Е. В. (ред), Лотмановский сборник. Москва: ИЦ-Гарант, 192-213.

Lotman, Yuri M. 1990. Universe of the Mind: A Semiotic Theory of Culture. London: I. B. Tauris.

- 2000. Лотман, Юрий М. Семиосфера. Санкт-Петербург: Искусство-СПБ.

Popovič, Anton 1975. Problémy literárnej metakomunikácie: Teória metatextu. Nitra: KLKEM.

Riffaterre, Michael 1994. Intertextuality vs. hypertextuality. New Literary History 25: 779-788.

Robel, Leon 1995 = Робель, Леон. Бахтин и проблема перевода. Новое литературное обозрение 11: 37-41.

Segers, Rien T. 2000. The cultural turn: The importance of the concept "cultural identity". In: Geest, D. de; Graef, O. de; Delabastita, D.; Geldof, K.; Ghesquière, R.; Lambert, J. (eds.), Under Construction: Links for the Site of Literary Theory (Essays in Honour of Hendrik van Gorp). Leuven: Leuven University Press, 367-388.

Shukman, Ann 1989. Semiotics of culture and the influence of M. M. Bakhtin. In: Eimermacher, Karl; Grzybek, Peter; Witte, Georg (eds.), Issues in Slavic Literary and Cultural Theory. Bochum: Universitätsverlag Dr. Norbert Brockmeyer, 193-207.

Todorov, Tzvetan 1982. La conquête de l'Amérique: La question de l'autre. Paris: Éditions du Seuil.

Torop 1995 = Тороп, Пеэтер. Тотальный перевод. Tartu: Tartu University Press.

Torop, Peeter 2000. La traduzione totale. Modena: Guaraldi Logos.

Toury, Gideon 1986. Translation. In: Sebeok, Thomas (ed.), Encyclopedic Dictionary of Semiotics, vol. 2. Berlin: Mouton de Gruyter, 1107-1124.

Venuti, Lawrence 1998. The Scandals of Translation: Towards an Ethics of Difference. London: Routledge.

\section{Перевод как переводческий процесс как культура}

В переводоведении традиционной трудностью является целостное историческое или синхроническое описание культуры перевода. С одной стороны, культуру перевода можно описать как сумму переводных текстов разного типа (репертуар культуры), с другой стороны - как иерархию типов перевода. Первый подход допускает обилие языков описания, второй подход предполагает существование единого языка описания. Те же проблемы стоят перед культурологом. Переводческая деятельность 
раскрывает, таким образом, важные аспекты механизма действия культуры. Во-первых, для понимания культуры плодотворны результаты семиотического поворота в переводоведении от Р. Якобсона до У. Эко, т.е. сопоставимость интерлингвистического, интралингвистического и интерсемиотического перевода. В результате всю культуру можно описать как процесс тотального перевода. Во-вторых, в семиотике культуры ценен синтез двух традиций (связанных с именами М. Бахтина и Ю. Лотмана), приводящий к сопоставимости понятий диалогичность и автономность-креолизация, полифоничность и гетерофоничность, противослово и перевод.

\section{Tõlge kui tõlkimine kui kultuur}

Tõlketeaduses on tavaraskuseks tõlkekultuuri terviklik ajalooline või sünkrooniline kirjeldamine. Ühelt poolt võib tõlkekultuuri vaadelda eritüübiliste tõlketekstide kogumina (kultuurirepertuaarina), teiselt poolt tõlketüüpide hierarhiana. Esimene lähenemisviis võimaldab erinevate kirjelduskeelte kasutamist, teine eeldab ühtse kirjelduskeele olemasolu. Samade probleemidega seisab silmitsi ka kulturoloog. Seega avanevad tõlketegevuses kultuuri toimemehhanismi olulised aspektid. Kõigepealt aitavad kultuuri paremale mõistmisele kaasa R. Jakobsoni ja U. Eco töödest tingitud semiootilise pöörde tulemused, interlingvistilise, intralingvistilise ja intersemiootilise tõlke kõrvutatavus. Selle tulemusel võib kõigepealt kogu kultuuri kirjeldada totaalse tõlkeprotsessina. Teiselt poolt muutub väärtuslikuks kahe kultuurisemiootilise, J. Lotmani ja M. Bahtini nimedega seostuva traditsiooni süntees, mis asetab kõrvuti mõisted dialoogilisus ja autonoomia-kreoliseerumine, polüfoonilisus ja heterofoonilisus, vastusõna ja ja tõlge. 